\title{
Note on Terminology and Transliteration
}

The term Moro as a designation for Muslims in the Philippines originates in Spanish history. The fall of the last Islamic state in Grenada in 1492 occurred mere decades before Magellan reached the Philippines, and memories of the Reconquista resonated among Catholic empire builders. Encountering Islamic populations on the Southeast Asian fringe, Spanish colonials used an act of naming to integrate these groups into their long conflict with North African Muslims. By virtue of their faith, Muslim Malays became "Moros" in the colonial imagination, just as the Christianized natives of the Northern Philippines became "Indios." The term Moro simply denoted that an ethnic group had undergone Islamization. An array of competing royal lineages existed in the Southern Philippines, as did differing cultural practices and adaptations of Islam. With some notable exceptions (explored within), Americans adopted these racial-religious taxonomies uncritically. Newspaper and magazine articles emphasized the unitary identity of Muslims, although sustained efforts to map the groups also occurred. Some civilian and military officials on the ground learned to appreciate the differences between Muslim societies in Mindanao and the Sulu Archipelago, yet the notion of "the Moro" remained. This reductionist approach had powerful effects on colonial policy.

I have struggled with the use of Moro as shorthand. The term carried negative connotations for many years, but in recent decades Muslim groups have reclaimed it and speak of the Bangsamoro (community or nation of Moro people) struggle. The term Filipino Muslims is likewise imperfect in its implicit suggestion that Islamic societies fit neatly into a national identity developed 
elsewhere in the archipelago. In the following, I use Moro and Muslim interchangeably for the sake of flow but wherever possible identify specific ethnic communities. I do not simply use Moro where Tausūg is applicable, for example. Nevertheless, I do analyze colonially generated primary source documentation where the term is used uncritically. This is most prevalent in the first chapter, which explores how Americans framed Muslim identities in the archipelago. Reducing diversity was a strategy of colonial rule, and I make every attempt to avoid doing so myself. Thirteen Moro groups live in the Southern Philippines: the Badjao, Iranun, Jama Mapun, Kalagan, Kalibugan, Maguindanao, Maranao, Molbog, Samal, Sangil, Tausūg, and Yakan. The Muslims who inhabit this work hail primarily from the four largest of these: Maguindanao, Maranao, Tausūg, and Samal (also referred to as the Sama-Bajau). The term Lumad is similarly flattening and refers to a diverse collection of indigenous peoples on Mindanao. These are groups American colonials referred to as "pagans" and in sum represent the animist indigenous peoples of the island. Included in the designation are the B'laan, Manobo, Bukidnon, Subanon, Mandaya, Sangil, Tagabawa, and other groups.

I acknowledge the problems inherent in using the term Americans to describe citizens of the United States. I deploy the term for stylistic reasons but recognize that it improperly gives a transcontinental identity to men and women of European descent from limited areas of North America. I use the shorthand colonials to describe Euro-American colonizers in the Southern Philippines. Here I take my lead from scholars writing on European colonies, particularly the example of the British Empire in India.

In cases where names originate in Arabic, I use the English-language spelling most common in the Philippines. This means occasional irregularities: Jamalul Kiram instead of Jamal al-Kiram, for example. I have applied standard transliterations of the many place-names, peoples, official titles, and regional products with Austronesian linguistic origins. In quoted material I have left alternate transliteration in place. There is a small glossary at the end of this book.

While the major island of Mindanao and the islands of the Sulu Archipelago are distinct spaces, I use the abbreviated designation Mindanao-Sulu when discussing the region itself. This should be read as the Muslim-majority areas of Western Mindanao and the Sulu island chain, and is condensed for readability. Those unfamiliar with the geography of the Muslim South should be aware that Jolo denotes both the name of the most populous island in the Sulu Archipelago and its largest settlement. When possible, I distinguish between the two by calling the latter Jolo town or the town of Jolo. 
Civilizational Imperatives 
